\title{
HIV interactions with monocytes and dendritic cells: viral latency and reservoirs Christopher M Coleman and $\mathrm{Li} \mathrm{Wu*}$
}

\author{
Address: Department of Microbiology and Molecular Genetics, Medical College of Wisconsin, 8701 Watertown Plank Road, Milwaukee, WI 53226, \\ USA \\ Email: Christopher M Coleman - ccoleman@mcw.edu; Li Wu* - liwu@mcw.edu \\ * Corresponding author
}

Published: I June 2009

Retrovirology 2009, 6:5 I doi:|0.1/86/I742-4690-6-5I

This article is available from: http://www.retrovirology.com/content/6/I/5I

This is an Open Access article distributed under the terms of the Creative Commons Attribution License (http://creativecommons.org/licenses/by/2.0), which permits unrestricted use, distribution, and reproduction in any medium, provided the original work is properly cited.

\begin{abstract}
$\mathrm{HIV}$ is a devastating human pathogen that causes serious immunological diseases in humans around the world. The virus is able to remain latent in an infected host for many years, allowing for the long-term survival of the virus and inevitably prolonging the infection process. The location and mechanisms of HIV latency are under investigation and remain important topics in the study of viral pathogenesis. Given that HIV is a blood-borne pathogen, a number of cell types have been proposed to be the sites of latency, including resting memory $\mathrm{CD}^{+} \mathrm{T}$ cells, peripheral blood monocytes, dendritic cells and macrophages in the lymph nodes, and haematopoietic stem cells in the bone marrow. This review updates the latest advances in the study of HIV interactions with monocytes and dendritic cells, and highlights the potential role of these cells as viral reservoirs and the effects of the HIV-host-cell interactions on viral pathogenesis.
\end{abstract}

\section{Background}

Human immunodeficiency virus (HIV) remains a devastating human pathogen responsible for a world-wide pandemic of acquired immunodeficiency syndrome (AIDS). Despite extensive research of HIV since the virus was identified over 25 years ago, eradication of HIV-1 infection and treatment of AIDS remain a long-term challenge $[1,2]$. The AIDS pandemic has stabilised on a global scale. In 2007, it was estimated that 30 to 36 million people world-wide were living with HIV, and 2.7 million people were newly infected with HIV. Moreover, AIDS-related deaths were increased from an estimated 1.7 million people in 2001 to 2.0 million in 2007. Africa continues to be over-represented in the statistics, with $68 \%$ of all HIV-positive people living in sub-Saharan countries. The young generation represents a large proportion of newly infected population who may contribute to the overall spread of HIV in the future [3].

There are two types of HIV, HIV-1 and HIV-2; both are capable of causing AIDS, but HIV-2 is slightly attenuated with regards to disease progression [4]. Given the relative severity of HIV-1 infection, the majority of studies have been done using HIV-1. The infection dynamics of HIV-1 are very interesting. Upon initial HIV-1 infection, there is a period of continuous viral replication and strong immune pressure against the virus, resulting in a relatively low steady state of viral load. The virus then enters a chronic stage, wherein there is limited virus replication and no outward signs of disease. This clinical phase can last many years, ultimately leading to destruction of the host immune system due to chronic activation or viral 
replication. This results in the onset of the AIDS stage with opportunistic infections and inevitable death in the vast majority of untreated patients [4].

Unfortunately, there is no effective AIDS vaccine currently available, and antiretroviral therapy is limited in its ability to fully control viral replication in infected individuals. Recent progress suggests that understanding how HIV interacts with the host immune cells is vitally important for the development of new treatments and effective vaccination regimens $[1,2]$. Monocytes, monocyte-differentiated dendritic cells (DCs) and macrophages are critical immune cells responsible for a wide range of both innate and adaptive immune functions [5]. These cell types also play multifaceted roles in HIV pathogenesis (Table 1). In this review, the potential roles of monocytes and DCs as HIV reservoirs and in latency will be discussed in detail.

\section{Monocytes interact with HIV-I Monocyte distribution and function}

Monocytes are vitally important cells in the immune system, as they are the precursor cells to professional antigenpresenting cells (APCs), such as macrophages and DCs. These types of immune cells patrol the bloodstream and tissues, replenishing dying APCs or, in an infection, providing enough of these cells for the body to effectively combat an invading pathogen [5]. Undifferentiated monocytes live for only a few days in the bloodstream. Upon differentiation or activation, the life-span of monocytes is significantly prolonged for up to several months [6].

There are two major subtypes of monocytes, those that are highly CD14-positive (CD14 $\left.{ }^{++} \mathrm{CD} 16^{-}\right)$and those that are CD16-positive $\left(\mathrm{CD} 14^{+} \mathrm{CD} 16^{+}\right)$. CD $16^{+}$cells make up only a small percentage (around 5\%) of the total monocyte population, but they are characterised as more proinflammatory and having a greater role in infections than the CD14 ${ }^{++}$CD16- cells [7].

\section{HIV infection of monocyte}

Although monocytes express the required HIV-1 receptors and co-receptors for productive infection $[8,9]$, they are not productively infected by HIV-1 in vitro. This is possibly due to an overall inefficiency in each of the steps required for virus infection, ranging from viral entry to proviral DNA integration [10-12], but not due to a viral nucleocapsid uncoating defect [13]. Recent studies have suggested a role for naturally occurring anti-HIV micro-RNA (miRNA) in suppressing HIV-1 replication in peripheral blood mononuclear cells or purified monocytes [14-17]. This mechanism could allow for further studies utilising miR-

Table I: Myeloid lineage cell types and their potential roles and proposed mechanisms in HIV-I latency

\begin{tabular}{|c|c|c|c|c|}
\hline Cell types & Primary Locations & Cellular markers & $\begin{array}{l}\text { Potential role in HIV latency and } \\
\text { proposed mechanisms }\end{array}$ & References \\
\hline Monocytes & Peripheral blood & $\begin{array}{l}\text { CDI4 } 4^{++} \\
\text {or CDI6+CDI4+ }\end{array}$ & $\begin{array}{l}\text { YES, but possibly mainly in CDI6+ cells } \\
\text { - Restricted HIV-I replication at different } \\
\text { steps of viral life-cycle } \\
\text { - Low molecular weight APOBEC3G (CDI6+ } \\
\text { only) } \\
\text { - Low level or undetectable Cyclin TI } \\
\text { - Impaired phosphorylation of CDK9 }\end{array}$ & {$[10-12,87-92,94]$} \\
\hline Macrophages & Mucosal surface/tissues & $\begin{array}{l}\mathrm{CDI}^{-} \\
\mathrm{EMRI}^{+} \\
\mathrm{CD}^{+}\end{array}$ & $\begin{array}{l}\text { NO } \\
\text { - High level Cyclin TI } \\
\text { - Phosphorylation of CDK9 and active P-TEFb }\end{array}$ & {$[14,18,94,97]$} \\
\hline Myeloid DCs & $\begin{array}{l}\text { Peripheral blood (immature) } \\
\text { Lymph node (mature) }\end{array}$ & $\begin{array}{l}\text { CDIIc } \\
\text { CDI23- } \\
\mathrm{BDCAI}^{+}\end{array}$ & $\begin{array}{l}\text { YES } \\
\text { - Low level virus replication } \\
\text { - Lymph node biopsies reveal presence } \\
\text { - Unknown mechanism }\end{array}$ & {$[101,107,112]$} \\
\hline Plasmacytoid DCs & $\begin{array}{l}\text { Peripheral blood (immature) } \\
\text { Lymph node (mature) }\end{array}$ & $\begin{array}{l}\text { CDIIc- } \\
\mathrm{CDI}_{23^{+}} \\
\mathrm{BDCA}^{+} \\
\mathrm{BDCA}^{+}\end{array}$ & $\begin{array}{l}\text { Unlikely } \\
\text { - Inhibiting HIV-I replication through the } \\
\text { secretion of IFN } \alpha \text { and an unidentified small } \\
\text { molecule } \\
\text { - Unknown mechanism }\end{array}$ & {$[49,50,101]$} \\
\hline Langerhans cells & Mucosal surface and epidermal tissue & $\begin{array}{l}\mathrm{CDIa}^{+} \\
\text {Langerin }^{+}\end{array}$ & $\begin{array}{l}\text { Unlikely } \\
\text { - Langerin inhibits virus transmission and } \\
\text { enhances virus take-up and degradation } \\
\text { - May act differently in co-infections }\end{array}$ & {$[40,4 \mathrm{I}, \mathrm{I} \mid 3]$} \\
\hline
\end{tabular}

EMRI, epidermal growth factor module-containing mucin-like receptor I (a G-protein coupled receptor); BDCA, blood DC antigen. 
NAs as inhibitors of HIV-1 [15]. However, it has also been shown that HIV-1 is capable of suppressing some inhibitory miRNAs [16], which may reflect an evolutional interaction between HIV-1 and host factors. Further studies are required to understand this interaction and develop a therapeutic approach against HIV-1 infection using miRNAs.

Differentiation of monocytes into macrophages or DCs in vitro enables productive HIV-1 replication in the differentiated cells $[14,18,19]$. Based on current understanding, vaginal macrophages are more monocyte-like than intestinal macrophages and show increased HIV-1 susceptibility [20]. Hence, some monocyte characteristics might be required for efficient infection, and these traits may be lost in fully differentiated tissue macrophages.

\section{Monocyte-HIV interactions that impact immune function} Given the role of monocytes in the immune system and in HIV-1 replication, a number of HIV-1 proteins have been shown to affect the biology of monocytes.

HIV-1 Tat-mediated transactivation of the viral promoter is essential for HIV-1 transcription [21]. Exogenous recombinant HIV-1 Tat protein has been shown to increase monocyte survival through increased expression of the anti-apoptotic protein $\mathrm{Bcl}-2$ [22]. Using an in vitro model of monocyte death mediated by TRAIL (tumour necrosis factor-alpha-related apoptosis inducing ligand), it has been shown that HIV-1 Tat encourages the survival of monocytes in situations where they would normally be cleared [22]. Exogenous HIV-1 Tat has been shown to cause production of the cytokine interleukin (IL)-10 from monocytes in vitro $[23,24]$. Significantly increased IL-10 levels were also observed in HIV/AIDS patients compared with healthy controls [25]. Furthermore, up-regulation of IL-10 production in HIV/AIDS patients has been correlated with increased levels of monocyte-secreted myeloid differentiation-2 and soluble CD14 [25]; both proteins are key molecules in the immune recognition of gramnegative bacterial lipopolysaccharide (LPS). Given that high levels of secreted CD14 have been associated with impaired responses to LPS [26], it has been proposed that the release of general immunosuppressant IL-10 by monocytes [27] facilitates the progression to AIDS [25].

HIV-1 Nef is a multifunctional accessory protein that plays an important role in viral pathogenesis [28]. Retroviral-mediated HIV-1 Nef expression in primary monocytes and a promonocytic cell line inhibits LPS-induced IL-12p40 transcription by inhibiting the JNK mitogenactivated protein kinases [29]. As an inducible subunit of biologically active IL-12, IL-12p40 plays a critical role in the development of cellular immunity, and its production is significantly decreased during HIV-1 infection [29]. This study implicates the importance of HIV-1 Nef in the loss of immune function and progression to AIDS.

HIV-1 matrix protein (p17) regulates a number of cellular responses and interacts with the $\mathrm{p} 17$ receptor (p17R) expressed on the surface of target cells [30]. Upon binding to the cell surface receptor p17R, exogenous HIV-1 matrix protein causes secretion of the chemokine monocyte chemotactic protein-1 (MCP-1, also known as CCL2) from monocytes [30]. MCP-1 potentially increases monocyte recruitment to the sites of HIV-1 infection, increasing the available monocyte pool for infection by HIV-1; this recruitment may be of critical importance given the relatively low rate of infection of this cell type [10-12].

HIV-1 and HIV-1-derived factors have been shown also to induce up-regulation of programmed death ligand-1 on monocytes in vitro $[31,32]$. This ligand, in complex with its receptor, programmed death-1, causes apoptosis of all T cell types [33] and a loss of anti-viral function in a manner similar to known immunosuppressive cytokines [34]. Together, these studies suggest that HIV-1 can impair virus-specific immunity by modulating immuno-regulatory molecules of monocytes and T cells.

Of the studies discussed above, those involving Tat, matrix protein and HIV-1-derived factors, were performed using recombinant or purified proteins, whereas the Nef study and the reports on the programmed death ligand-1 were performed using infectious viruses and nef-deleted HIV-1 mutants. Although these results shed light on the influence of individual viral proteins on monocytes in vitro, synergistic or antagonistic effects of HIV-1 proteins on cellular responses cannot be ruled out, nor can the roles played by other host factors in vivo be excluded.

Overall, HIV-1 appears to promote the survival of monocytes as a key step for viral persistence. The interactions between the virus and monocytes may contribute key functions in establishing chronic HIV-1 infection and facilitating the progression to AIDS. These outcomes are likely influenced by the altered immunological function of monocytes and their interactions with other types of HIV-1 target cells (Figure 1).

\section{DCs interact with HIV Immune function of DCs}

DCs are professional APCs that are differentiated from monocytes in specific cytokine environments. DCs bridge the innate and adaptive immune responses, as they endocytose and break down invading pathogens in the endolysosome or proteasome and present antigen fragments to T cells, usually in the context of major histocompatability complexes [5]. There are three major DC subtypes: myeloid DCs, plasmacytoid DCs (pDC), and 


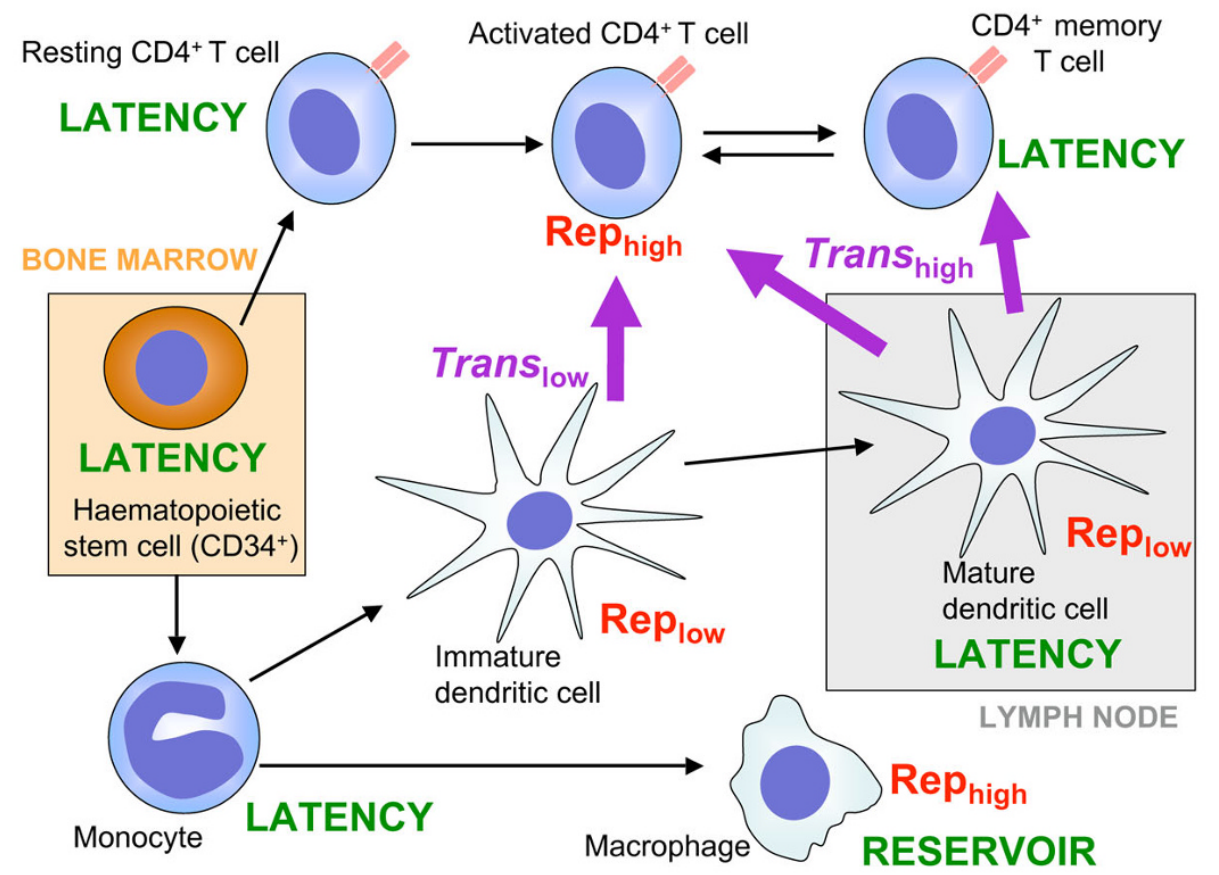

\section{Figure I}

Locations of HIV-I replication and latency and routes of transmission between haematopoietic cell populations. All cell types shown are susceptible to HIV-I entry and integration of the proviral DNA. Some anatomical locations are shown; those outside of marked areas are in the bloodstream, lymphatic system and/or tissues. Black arrows represent differentiation and/or maturation and may represent more than one step and could involve multiple intermediate cell types. Purple arrows represent routes of trans infection, and relative rates are shown as high or low. "Rep" indicates productive HIV-I replication with relative rates shown as high or low. HIV-I cis infection routes are not shown, as any susceptible cell may be infected by productive replication from another cell. Those cells in which HIV-I latency is thought to occur should be considered as putative viral reservoirs and therapeutic targets.

Langerhans cells. These DC subtypes are characterised based on their locations, surface markers and cytokine secretion profiles [5].

DC life-span and survival are highly dependent on their anatomical locations and the DC subtypes [35]. In general, DC half-lives measure up to a few weeks, and they can be replaced through proliferating hematopoietic progenitors, monocytes, or tissue resident cells [35]. It has been shown that productive HIV-1 replication occurs in human monocyte-derived DCs for up to 45 days [36]. DCs may survive longer within the lymph nodes due to cytokine stimulation in the microenvironment, which may help spread HIV-1 infection and maintain viral reservoirs.

\section{HIV infection of DCs}

HIV-1 is capable of directly infecting different DC subtypes (known as cis infection), but at a lower efficiency than HIV-1's ability to infect activated CD4+ T cells; therefore, only a small percentage of circulating DCs are positive for HIV in infected individuals [19]. Productive HIV1 replication is dependent on fusion-mediated viral entry in monocyte-derived DCs [37], and mature HIV-1 particles are localised to a specialised tetraspanin-enriched sub-compartment within the DC cytoplasm [38].

Langerhans cells are present in the epidermis or mucosal epithelia as immune sentinels [39]. It is interesting that Langerhans cells have been shown to be resistant to HIV1 infection [40]. This resistance appears to be due to the expression of Langerin, which causes internalisation and break-down of HIV-1 particles and blocks viral transmission [40]. However, in the context of co-infection with other sexually transmitted organisms, such as the bacterium Neisseria gonorrhoeae and/or the fungus Candida albacans [41] or when stressed by skin abrasion [42], Langerhans cells can become more susceptible to HIV-1 
infection and are able to transmit HIV-1 to CD4+ $\mathrm{T}$ cells effectively [42].

Drug abuse can significantly facilitate HIV infection, transmission and AIDS progression through drug-mediated immunomodulation. Recent studies have suggested that the recreational drug, methamphetamine, increases susceptibility of monocyte-derived DCs to HIV-1 infection in vitro [43] and blocks the antigen presentation function of DCs [44]. Although its relevance to the in vivo situation is unclear, this finding is potentially a further risk factor (aside from the use of contaminated needles, etc.) associated with drug use and may explain the high levels of HIV-prevalence among drug abusers.

HIV-1 infection of DCs likely contributes to viral pathogenesis. Notably, HIV-2 is much less efficient than HIV-1 at infecting both myeloid DCs and pDCs, whilst retaining its infectivity of $\mathrm{CD} 4^{+} \mathrm{T}$ cells [45]. This observation offers an explanation for the decreased pathogenicity of HIV-2, since HIV-2 will need to infect CD4+ ${ }^{+}$cells directly and, perhaps more importantly, resting or memory $\mathrm{CD} 44^{+} \mathrm{T}$ cells to ensure long-term survival of the virus.

\section{DC-HIV interactions that impact the immune function} Given the important roles DCs play in the immune response, it is reasonable that HIV-1 proteins or the virus itself have been shown to affect the function of DCs in vitro. Both HIV-1 matrix and Nef proteins have been shown to cause only partial maturation of pDCs in vitro $[46,47]$. In the presence of these viral proteins, DCs acquire a migratory phenotype, facilitating travel to the lymph nodes. However, these DCs do not express increased levels of activation markers, such as the T cell co-stimulatory molecules CD80 and CD86, or MHC class II, that would lead to a protective immune response $[46,47]$. It is possible, therefore, that the DCs are trapped in the lymph nodes and unable to initiate a protective immune response against the virus. The study of Nef protein's effects on DCs [47] was performed using a mouse DC model in vitro and an immortalised cell line; hence the full relevance of this finding to the in vivo situation is unclear.

Conversely, recombinant Nef protein appears to cause DC activation and differentiation by up-regulating the expression of CD80, CD86, MHC class II and other markers, as well as various cytokines and chemokines associated with $\mathrm{T}$ cell activation [48]. These effects have led to the proposition that Nef protein is capable of causing bystander activation of T cells via DCs [48], although this activity has not been demonstrated experimentally. Of note, the above study was performed using recombinant Nef alone.

DCs could contribute largely to an anti-HIV innate immunity. It has been demonstrated that pDCs are capable of inhibiting HIV-1 replication in T cells when cultured together in vitro $[49,50]$, implicating the importance of pDCs for viral clearance. HIV-1 infected individuals are known to have lower levels of circulating pDCs compared with those of uninfected individuals [51]. It has been confirmed that HIV-1 is capable of directly killing pDCs [49], illustrating that the virus can remove a potential block to its replication and dissemination in pDCs.

HIV-1 can block CD4+ $\mathrm{T}$ cell proliferation or induce the differentiation of naive $\mathrm{CD} 4+\mathrm{T}$ cells into $\mathrm{T}$ regulatory cells through pDCs $[52,53]$. These mechanisms involve HIV-1induced expression of indoleamine 2,3-deoxygenase in pDCs. Indoleamine 2,3-deoxygenase is a $\mathrm{CD} 4{ }^{+} \mathrm{T}$ cell suppressor and regulatory $\mathrm{T}$ cell activator [52,53]. HIV-1 envelope protein gp120 has also been shown to inhibit activation of $\mathrm{T}$ cells by monocyte-derived DCs [54], suggesting that gp120 may also have a role in the suppression of $\mathrm{T}$ cell function and progression to AIDS.

In addition, HIV-1 has been shown to suppress the immune function of pDCs in general by suppressing activation of the anti-viral toll-like receptor 7 (TLR7) and TLR8 [55], and by blocking the release of the anti-viral interferon alpha [56]. A recent study indicated that divergent TLR7 and TLR9 signalling and type I interferon production in pDCs contribute to the pathogenicity of simian immunodeficiency virus (SIV) infection in different species of macaques [57]. These results suggest that chronic stimulation of pDCs by SIV or HIV in non-natural hosts may induce immune activation and dysfunction in AIDS progression [57]. Overall, HIV-1 inhibits the function of pDCs to allow maintenance of the virus within the host.

\section{DC-mediated HIV-I trans infection}

The most interesting aspect of HIV-1 infection in DCs is the ability of the cells to act as mediators of trans infection of activated CD4 $4^{+} \mathrm{T}$ cells, which is the most productive cell type for viral replication. DC-mediated HIV-1trans infection of CD4+ $\mathrm{T}$ cells is functionally distinct from cis infection $[58,59]$ and involves the trafficking of whole virus particles from the DCs to the T cells via a 'virological synapse' $[59,60]$. Previous reviews have summarised the understanding of HIV-DC interactions [19,61]; so here we focus on discussing the latest progress in this field.

DC-mediated HIV-1 trans infection of CD4+ $4^{+}$cells is dependent on, or enhanced by, a number of other cellular and viral factors. CD4 co-expression with DC-SIGN (DCspecific intercellular adhesion molecule 3-grabbing nonintegrin), a C-type lectin expressed on DCs, inhibits DCmediated trans infection by causing retention of viral particles within the cytoplasm [62]. HIV-1 Nef appears to enhance DC-mediated HIV-1 trans-infection. Nefenhanced HIV-1 transmission efficiency correlates with significant CD4 down-regulation in HIV-1-infected DCs 
[62]. Furthermore, the maturation state of the DCs appears to be important for trans infection, with mature DCs showing greater HIV trafficking ability than immature DCs [59,63-65]. These results have highlighted the proposed model that immature DCs might endocytose the virus in the periphery and then transfer it to CD4+ $\mathrm{T}$ cells upon DC maturation in the lymph node [19].

Recent studies have revealed that the precise trafficking of the endocytosed HIV virion, with regard to the sub-cellular vesicle trafficking networks [64] and cytoskeletal rearrangements associated with synapse formation [63], is critical for trans infection in mature DCs. The host cellderived glycosphingolipid composition of the viral particle also appears to be important for both the capture of virus in mature and immature DCs and the trans infection process [66]. Our recent results suggest that intracellular adhesion molecule-1 (ICAM-1), but not ICAM-2 or ICAM-3, is important for DC-mediated HIV-1 transmission to $\mathrm{CD} 4{ }^{+} \mathrm{T}$ cells [67]. The interaction between ICAM1 on DCs and leukocyte function-associated molecule 1 (LFA-1) on T cells plays an important role in DC-mediated HIV-1 transmission [68]. This mechanism might be specific for DC-mediated transmission of HIV-1 to CD4 ${ }^{+} \mathrm{T}$ cell, as in vitro experiments blocking LFA-1 on HIVinfected $\mathrm{CD} 4{ }^{+} \mathrm{T}$ cells have shown no effect on virus transmission to non-infected T cells [69]. In addition, purified host surfactant protein $\mathrm{A}$ in the mucosa has been shown to enhance DC-mediated HIV-1 transfer by binding to the viral envelope glycoprotein, gp120 [70]. This study also showed that surfactant protein A inhibited the direct infection of $\mathrm{CD}^{+} \mathrm{T}$ cells [70], suggesting a selection pressure for DC-mediated trans infection at mucosal surfaces.

The precise mechanism of virus transfer from DCs to $\mathrm{CD} 4{ }^{+} \mathrm{T}$ cells has yet to be determined [19]. Recent studies have demonstrated a role for small lipid vesicles known as exosomes in immature and mature DC-mediated HIV-1 transmission to $\mathrm{CD}^{+} \mathrm{T}$ cells $[66,71,72]$. Immature DCs are capable of constitutively releasing infectious virus in association with exosomes in the absence of $\mathrm{CD} 4{ }^{+} \mathrm{T}$ cells [71]. HIV-1 and purified exosomes can be endocytosed by mature DCs into the same intracellular compartment and transferred to co-cultured $\mathrm{CD}^{+} \mathrm{T}$ cells [72], suggesting that HIV-1 may exploit an intrinsic exosome trafficking pathway in mature DCs to facilitate viral dissemination. Although interesting for infectious dynamics, these observations on exosome-mediated viral transmission do not sufficiently explain the mechanisms of HIV-1 trans infection. How these models relate to the in vivo situation of DC-mediated HIV-1 transmission is unclear, given that DCs can traffic to the lymph node and effectively transfer virus to CD4+ $\mathrm{T}$ cells [19]. If DCs release HIV-1 in association with exosomes in the tissue as DCs migrate to lymph nodes [71], or if DCs require $\mathrm{T}$ cell activation for the release of exosome-associated HIV-1 [72], the viral transmission process might be very inefficient in vivo.

Recent studies have also offered the intriguing possibility that HIV-1 can be transferred from cell to cell via cell protrusions, with the virus either transmitting via cellular membrane nanotubes [73] or 'surfing' along the extracellular surface of the cytoplasmic membrane [74]. HIV-1 intracellular trafficking is dependent on the viral envelope protein on the membrane of an infected cell to form a stable complex with the protrusion from an uninfected cell [73]. This mechanism of viral transmission may be an adaptation of a normal cellular cross-talk process that is used in normal cellular communication, for example, by DCs and $\mathrm{T}$ cells during immunological synapse formation. Limitations to the above studies are that they were performed in either $\mathrm{CD}^{+} \mathrm{T}$ cells alone [73], immortal $\mathrm{CD} 4{ }^{+} \mathrm{T}$ cells $[74]$, or mainly using a mouse retroviral model [74]. Indeed, the potential mechanisms of cell-cellmediated HIV transmission have yet to be investigated in the DC-T cell trans infection model.

Inhibition of cell-cell mediated HIV-1 transmission can be developed into future therapeutic approaches. Because of the importance of DC-mediated trans infection of $\mathrm{CD} 4{ }^{+} \mathrm{T}$ cells, a number of recent studies have identified factors that block this process, such as the C-type lectin, Mermaid, and natural anti-DC-SIGN antibodies in breast milk [75-78]. However, the therapeutic efficacy of these factors has yet to be established.

HIV-2 is incapable of being transferred from DCs [45]; and, coupled with its overall lack of cis infection of DCs, these data may explain why HIV-2 is less pathogenic than HIV-1.

\section{Potential role of monocytes and DCs in HIV-I latency and reservoirs}

In general, latency refers to the absence of gene expression of a pathogen in the infected hosts or cells, serving to ensure the long-term survival of the pathogen. Latency is an important step for a number of viral pathogens including HIV and other retroviruses [79-82]. Latency allows for the release of new viruses over an extended period of time and avoids short-term immune responses. The site of latency can form a viral reservoir, from which a virus can initiate new infections of naïve cells.

The critical aspect for supporting a viral reservoir is a cell type that will stay alive for a long time in order to preserve the virus. It has been shown that even with anti-retroviral therapy, low levels of HIV-1 viremia are maintained within the plasma of patients for at least 7 years [83]. Given that HIV- 1 causes CD $4^{+}$T-cell depletion and compromised immunological functions associated with AIDS 
[84], most CD4+ T-cells are not sufficient for long-term maintenance of the virus. However, long-lived memory $\mathrm{CD}^{+} \mathrm{T}$ cells can play an important role in HIV-1 latency $[85,86]$. This reservoir can persist for a long time during antiretroviral treatment; indeed, one study has suggested a viral half-life of 44 months [86], and another recent study showed survival of virus in the reservoir for 8.3 years without significant viral mutation [85]. These results suggest that the viral reservoir is protected from antiretroviral treatment and that it is capable of initiating new infections when the treatment is stopped.

Both monocytes and certain subsets of DCs have also been proposed as sites of HIV-1 latency (Figure 1 and Table 1).In vivo or ex vivo studies of HIV latency are generally performed using clinical samples from infected individuals undergoing antiretroviral therapy. The antiretroviral therapy may clear any easily accessible replicating virus and allow study of only the long-term HIV-l reservoirs.

\section{Role of monocytes}

Monocytes are implicated as a viral reservoir based on the detection of, or the recovery of, infectious virus from monocytes isolated from HIV-positive individuals on antiretroviral therapy [87-91]. It appears that CD16-positive monocytes (5\% of monocyte population [7]) are both more susceptible to infection and preferentially harbour the virus long-term $[92,93]$, perhaps explaining why only small numbers of monocytes are infected by HIV-1 in vitro. CD14 ${ }^{++}$monocytes express high levels of the low molecular weight form of APOBEC3G (apolipoprotein B mRNA-editing enzyme, catalytic polypeptide-like 3G), which is associated with anti-HIV activity, whereas CD16 $6^{+}$ monocytes express the high molecular weight form of APOBEC3G that has no anti-HIV activity [92].

The mechanism of HIV-1 latency in monocytes is not fully understood. Recent data suggest that the inhibition of viral replication is host mediated, at least in part, through a lack of the expression of key co-factors for the HIV-1 Tat protein. It appears that the transcription of the integrated viral genome, as transactivated by the viral Tat protein, is inhibited [94]. Tat binds to the $5^{\prime}$ long terminal repeat sequence of the integrated genome in complex with two host proteins, cyclin T1 (CycT1) and cyclin-dependent kinase 9 (CDK9), collectively known as the positive transcription elongation factor b (P-TEFb) $[21,95,96]$. Monocytes, when compared with activated $\mathrm{CD} 4^{+} \mathrm{T}$ cells and macrophages [96], are known to have much lower levels of CycT1 expression [94,97], therefore, they lack functional P-TEFb. However, this is not the only factor responsible for the resistance of monocytes to HIV-1 replication, as transient expression of CycT1 is not sufficient to restore HIV-1 Tat-mediated transactivation in monocytes [94].
Cell-cell fusion of monocytes and a HIV-1-permissive cell line restores Tat-mediated transactivation [94]. Phosphorylation of CDK9 is known to be vital for the formation of a P-TEFb complex and for Tat-mediated transcription of the HIV-1 promoter [98]. Despite having the same levels of CDK9, monocytes have low levels of the active, phosphorylated CDK9 form as compared with macrophages, and this phenotype has been directly correlated with the poor ability of monocytes to support HIV-1 replication [94]. In addition, the basal transcription from the HIV-1 LTR in undifferentiated primary monocytes was reported to be undetectable using a transient transfection assay [94].

Studying HIV-1 latency in monocytes is challenging due to generally low viral integration and infection of monocytes [94]. However, even when a HIV-1 proviral DNA construct is transfected directly into monocytes, there is no infectious virus production [94]. When monocytes differentiate into macrophages, they become increasingly susceptible to HIV-1 infection and permissive to viral gene expression and production of infectious viruses [94]. Furthermore, the differentiation of monocytes into macrophages stimulates HIV-1 production in the infected monocytes [94], suggesting a role played by monocytes in both viral latency and reactivation.

\section{Contribution of DCs}

Because of the ability of DCs to transfer virus to CD4 $4^{+} \mathrm{T}$ cells, it is conceivable that DCs may act as reservoirs for HIV-1 and 'dose' T cells with the virus over extended periods. DCs are capable of transmitting HIV-1 to T cells over a period of several days, and the viral transmission is dependent on viral replication [99-101]. It is possible, therefore, that long-term transfer of HIV-1 to T cells is actually through cis infection, while trans infection is only present in the very early stages [58]. This HIV-1 transmission process may be 'trans-like', for example HIV-1 may assemble in endosomes or other intracellular membrane domains in a similar manner as described in macrophages $[102,103]$, then the virus may be transmitted across a virological synapse. However, the precise mechanism of virus assembly within macrophages remains a source of debate [104,105].

The ability of DCs to act as reservoirs of HIV-1 appears to be highly dependent on the DC sub-type. Follicular DCs (FDCs) have been shown to retain infectious viral particles on their surface, and the retained virus is capable of being transferred to CD4+ T cells [106-110]. FDCs in HIV1 positive individuals harbour genetically diverse viral strains that are not observed elsewhere in the body [111], indicating that these cells may act as focal points for the rapid emergence of mutations observed in HIV-1 infected individuals. 
It also appears that peripheral blood myeloid DCs do not harbour the virus in vivo during antiretroviral therapy [112], suggesting that it is the DCs in the lymph nodes that act as the long-term reservoir. This thinking is further supported by other studies that found HIV-1 in association with myeloid DCs that were isolated from lymph node biopsies or necropsies of individuals on antiretroviral therapy [107]. Conversely, a recent study has suggested that Langerhans cells isolated from the oral cavity of HIV1 positive individuals do not act as reservoirs for HIV-1, despite HIV-1 detection within whole tissue samples from the area [113]. This result is perhaps not surprising given the effect of Langerin on inhibiting HIV-1 transmission [40]. Moreover, pDCs have also not been implicated as reservoirs of HIV-1, which may be due to inhibiting HIV1 replication through the secretion of IFN $\alpha$ and an unidentified small molecule by pDCs $[49,50]$.

\section{Role of monocytic precursor cells}

HIV-1 is capable of altering the biology of haematopoietic stem cells in vivo, primarily affecting $\mathrm{T}$ cell development [114-116]. Undifferentiated monocytic precursor cells, such as CD34+ stem cells or partially differentiated haematopoietic precursor cells, may act as reservoirs $[117,118]$. These cells in the bone marrow will be relatively shielded from antiviral treatments and may act as the ultimate long-term reservoir of HIV-1 (Figure 1). This mechanism allows for transmission of the virus because the progenitor cells containing integrated HIV-1 genomes will proliferate, differentiate and pass on the virus to progeny monocytes. Indeed, the ability to harbour genes and transfer them to progeny cells makes stem cells attractive targets for gene therapy against HIV1 infection $[119,120]$.

\section{Other proposed mechanisms}

There have been a number of studies that have proposed other mechanisms for latency in $\mathrm{CD} 4^{+}$memory T cells. It is possible that these mechanisms also have roles in latency in monocytes and/or DCs, but this remains to be investigated.

It has been proposed that the host cell itself can play a role through inhibition of HIV-1 gene transcription. In a CD4 ${ }^{+}$ $\mathrm{T}$ cell line and a yeast model of HIV-1 transcription, host chromatin structures slowly accumulate (in one study over 30 days [121]) on the long terminal repeat of the integrated viral genome and inhibit viral gene transcription $[121,122]$. Moreover, recent studies have suggested a much broader role for host transcription factors in HIV-1 latency in CD4+ $\mathrm{T}$ cells [123-125].

In light of the evidence that suggests miRNAs play a role in the resistance of monocytes to HIV-1 infection [14,15], it is of interest that a number of host miRNAs have been implicated in causing latency in resting primary $\mathrm{CD} 4{ }^{+} \mathrm{T}$ cells [126]. Inhibitors of these miRNAs are now being touted as a new generation of treatment to be used in concert with current antiretrovirals [reviewed in [127]].

In resting $\mathrm{CD} 4^{+} \mathrm{T}$ cells from HIV-1-infected individuals, HIV-1 multiply spliced RNA transcripts are retained in the nucleus and cannot be translated into functional proteins [128]. The lack of a host transcription factor, polypyrimidine tract binding protein, appears to account for the underlying mechanism in resting CD4 ${ }^{+} \mathrm{T}$ cells. Transient expression of this host protein induces productive HIV-1 replication in resting $\mathrm{CD} 4{ }^{+} \mathrm{T}$ cells that are isolated from HIV-1-positive individuals [128].

However, HIV-1 latency is not always restricted to resting $\mathrm{CD} 4^{+} \mathrm{T}$ cells or explained by limiting cellular factors. In some instances, HIV-1 latency is due to replicative selection for specific viral characteristics. It has been shown that a doxycycline-dependent HIV-1 variant is capable of establishing latency within a dividing $\mathrm{CD} 4^{+} \mathrm{T}$ cell type (SupT1 cell line) normally permissive for viral replication [129]. This study showed that only a small proportion $(0.1 \%-10 \%)$ of an inducible provirus was rescued from the cells after addition of the inducing doxycycline drug, indicating that HIV-1 is capable of establishing latency in the majority of actively dividing cells. Thus, in some settings, HIV-1 proviral latency is not limited to resting $\mathrm{T}$ cells, but can be due to intrinsic viral traits [129].

\section{Conclusion and future directions}

Latency in HIV infection is a key area of study for understanding the pathogenesis and ultimate development of therapies or vaccinations against HIV/AIDS. Figure 1 shows an overview of the known or proposed interactions between HIV-1 and various cells of the haematopoietic system. Moreover, myeloid lineage cell types and their potential roles and proposed mechanisms in HIV-1 latency are summarized in Table 1.

Efforts to tackle HIV latency may ultimately fall into two key areas, blocking the development of the latency and reactivating viral reservoirs in chronically infected individuals to clear the virus. Both aspects will require extensive understanding of the mechanisms of HIV latency $[1,2]$. Given that monocytes and DCs have been implicated as HIV-1 reservoirs using in vitro and ex vivo models of viral infection (Table 1), further understanding of the mechanisms of latency within these cells is an important area of research. Although much is known about the ways in which HIV-1 interacts with both monocytes and the various types of DCs, some key questions remain to be answered to fully understand the pathogenesis and latency of HIV-1. For instance, the relative contributions of the proposed cell types in the process of HIV latency 
and molecular mechanisms in both viral and host aspects remain to be elucidated.

The latent phase is of particular interest for the development of novel anti-HIV interventions. The HIV and hostfactor interactions described here represent potential targets for both drug and vaccination efforts. Given that HIV1 has a very intimate relationship with host cells, blocking known host factors responsible for certain viral effects could have catastrophic consequences for the host. For example, blocking DC factors responsible for virological synapse formation may also switch off the formation of the immunological synapses that arise in response to HIV or other pathogen infections. The ultimate hope would be to find either a viral factor or non-essential host factors that can be removed without damage to the host. As a successful example, the CCR5 co-receptor is now a target of both HIV-1 gene therapy and antiretroviral therapy $[130,131]$. Based on studies into the role of DCs in HIV-1 pathogenesis, there are also a number of post-exposure vaccine clinical trials, wherein DCs are exposed ex vivo with HIV-1 or HIV-1 antigens and then re-introduced into the HIV-positive individual in an effort to elicit a protective immune response [reviewed in [132]].

Development of in vitro models of HIV-1 latency can be extremely complex. While there are examples of complex tissue culture models of in vivo systems for a range of human pathogens, including HIV-1, these models involve predominantly epithelial cells and various leukocytes $[133,134]$. Cell culture-based models containing only subsets of leukocytes have limitations, because it is impossible to compartmentalise the cells in exactly the same fashion as observed in vivo (as in lymph nodes, for example). There are also many important technical issues with isolation, maintenance and establishment of in vitro studies of HIV-1 latency [reviewed in [135]].

In vivo or ex vivo model systems remain the best options for studying long-term HIV-1 latency. SIV strains that are closely related to HIV and display the same initial infection and latency characteristics can be used as attractive models to study viral latency. Mice are generally not susceptible to HIV-1, or at least not in a physiologically relevant manner. Recently, 'humanised' mice have become available in HIV-1 research [reviewed in [136]]. The humanised mouse model potentially offers a viable alternative to non-human primates for studying HIV-1 molecular pathogenesis and for designing novel therapies that block HIV-1 infection [137].

\section{Abbreviations}

HIV-1: human immunodeficiency virus type 1; HIV-2: human immunodeficiency virus type 2; SIV: simian immunodeficiency virus; DCs: dendritic cells; pDC: plas- macytoid DCs; APCs: antigen-presenting cells; CD: cluster of differentiation; IL: interleukin; LPS: lipopolysaccharide; TLR: toll-like receptor.

\section{Competing interests}

The authors declare that they have no competing interests.

\section{Authors' contributions}

Both authors contributed to the writing and editing of the manuscript.

\section{Acknowledgements}

We thank Dr. Kuan-Teh Jeang for critical comments and helpful suggestions on the manuscript. We thank the members of the Wu laboratory for critical reading of the manuscript and helpful discussions. The research of the Wu laboratory is supported by grants from the National Institutes of Health (Al068493 and Al078762), the Advancing a Healthier Wisconsin Program of the Medical College of Wisconsin, and the Johnson and Pabst LGBT Humanity Fund to LW. The authors apologize to all those whose work has not been cited as a result of space limitations.

\section{References}

I. Kallings LO: The first postmodern pandemic: $\mathbf{2 5}$ years of HIVI AIDS. J Intern Med 2008, 263:218-243.

2. Richman DD, Margolis DM, Delaney M, Greene WC, Hazuda D, Pomerantz RJ: The challenge of finding a cure for HIV infection. Science 2009, 323:1304-1307.

3. UNAIDS: Report on the Global AIDS Epidemic. 2008

4. Fields BN, Knipe DM, Howley PM: Fields' virology 5th edition. Edited by: David M Knipe, Peter M Howley, Diane E Griffin, et al. Philadelphia, Pa.; London: Wolters Kluwer/Lippincott Williams \& Wilkins; 2007.

5. Abbas AK, Lichtman AH: Cellular and molecular immunology 5th edition. Philadelphia, Pa.; London: W. B. Saunders; 2003.

6. Gonzalez-Mejia ME, Doseff Al: Regulation of monocytes and macrophages cell fate. Front Biosci 2009, I 4:24I3-243 I.

7. Ziegler-Heitbrock L: The CDI4+ CDI6+ blood monocytes: their role in infection and inflammation. J Leukoc Biol 2007, $81: 584-592$

8. Filion LG, Izaguirre CA, Garber GE, Huebsh L, Aye MT: Detection of surface and cytoplasmic CD4 on blood monocytes from normal and HIV-I infected individuals. J Immunol Methods 1990, 135:59-69.

9. Naif HM, Li S, Alali M, Sloane A, Wu L, Kelly M, Lynch G, Lloyd A, Cunningham AL: CCR5 expression correlates with susceptibility of maturing monocytes to human immunodeficiency virus type I infection. J Virol 1998, 72:830-836.

10. Arfi V, Riviere L, Jarrosson-Wuilleme L, Goujon C, Rigal D, Darlix JL, Cimarelli A: Characterization of the early steps of infection of primary blood monocytes by human immunodeficiency virus type I. J Virol 2008, 82:6557-6565.

II. Triques K, Stevenson M: Characterization of restrictions to human immunodeficiency virus type I infection of monocytes. J Virol 2004, 78:5523-5527.

12. Sonza S, Maerz A, Deacon N, Meanger J, Mills J, Crowe S: Human immunodeficiency virus type I replication is blocked prior to reverse transcription and integration in freshly isolated peripheral blood monocytes. J Virol 1996, 70:3863-3869.

13. Srichatrapimuk S, Auewarakul P: Resistance of monocyte to HIVI infection is not due to uncoating defect. Virus Res 2007, I 26:277-28I.

14. Wang X, Ye L, Hou W, Zhou Y, Wang YJ, Metzger DS, Ho WZ: Cellular microRNA expression correlates with susceptibility of monocytes/macrophages to HIV-I infection. Blood 2009, I | 3:67|-674.

15. Sung TL, Rice AP: miR-I98 inhibits HIV-I gene expression and replication in monocytes and its mechanism of action appears to involve repression of cyclin TI. PLoS Pathog 2009, 5:el000263. 
16. Triboulet R, Mari B, Lin YL, Chable-Bessia C, Bennasser Y, Lebrigand K, Cardinaud B, Maurin T, Barbry P, Baillat V, et al:: Suppression of microRNA-silencing pathway by HIV-I during virus replication. Science 2007, 3 15:1579-1582.

17. Ahluwalia JK, Khan SZ, Soni K, Rawat P, Gupta A, Hariharan M, Scaria V, Lalwani M, Pillai B, Mitra D, Brahmachari SK: Human cellular microRNA hsa-miR-29a interferes with viral nef protein expression and HIV-I replication. Retrovirology 2008, 5: I I7.

18. Collman R, Hassan NF, Walker R, Godfrey B, Cutilli J, Hastings JC Friedman $\mathrm{H}$, Douglas SD, Nathanson N: Infection of monocytederived macrophages with human immunodeficiency virus type I (HIV-I). Monocyte-tropic and lymphocyte-tropic strains of HIV-I show distinctive patterns of replication in a panel of cell types. J Exp Med 1989, 170:1 I49-1 I63.

19. Wu L, KewalRamani VN: Dendritic-cell interactions with HIV: infection and viral dissemination. Nat Rev Immunol 2006, 6:859-868.

20. Shen R, Richter HE, Clements RH, Novak L, Huff K, Bimczok D, Sankaran-Walters S, Dandekar S, Clapham PR, Smythies LE, Smith PD: Macrophages in Vaginal but not Intestinal Mucosa are Monocyte-like and Permissive to HIV-I. J Virol 2009, 83:3258-3267.

21. Nekhai S, Jeang KT: Transcriptional and post-transcriptional regulation of HIV-I gene expression: role of cellular factors for Tat and Rev. Future Microbiol 2006, I:4I7-426.

22. Zheng L, Yang Y, Guocai L, Pauza CD, Salvato MS: HIV Tat protein increases $\mathrm{Bcl}-2$ expression in monocytes which inhibits monocyte apoptosis induced by tumor necrosis factor-alpharelated apoptosis-induced ligand. Intervirology 2007, 50:224-228.

23. Leghmari K, Bennasser Y, Bahraoui E: HIV-I Tat protein induces IL- 10 production in monocytes by classical and alternative NF-kappaB pathways. Eur J Cell Biol 2008, 87:947-962.

24. Leghmari K, Bennasser Y, Tkaczuk J, Bahraoui E: HIV-I Tat protein induces IL- 10 production by an alternative TNF-alpha-independent pathway in monocytes: role of PKC-delta and p38 MAP kinase. Cell Immunol 2008, 253:45-53.

25. Sandanger $O$, Ryan L, Bohnhorst J, Iversen $A C$, Husebye $H, H$ alaas $O$ Landro L, Aukrust P, Froland SS, Elson G, et al: IL- 10 enhances MD-2 and CDI 4 expression in monocytes and the proteins are increased and correlated in HIV-infected patients. J Immunol 2009, 182:588-595.

26. Grunwald U, Fan X, Jack RS, Workalemahu G, Kallies A, Stelter F, Schutt C: Monocytes can phagocytose Gram-negative bacteria by a CDI4-dependent mechanism. J Immunol 1996, I 57:41 19-4I25.

27. Moore KW, de Waal Malefyt R, Coffman RL, O'Garra A: Interleukin- 10 and the interleukin- 10 receptor. Annu Rev Immunol 200I, 19:683-765.

28. Foster JL, Garcia JV: HIV-I Nef: at the crossroads. Retrovirology 2008, 5:84.

29. Ma W, Mishra S, Gajanayaka N, Angel JB, Kumar A: HIV-I Nef inhibits lipopolysaccharide-induced IL-I 2p40 expression by inhibiting JNK-activated NFkappa B in human monocytic cells. I Biol Chem 2008, 284:7578-87.

30. Marini E, Tiberio L, Caracciolo S, Tosti G, Guzman CA, Schiaffonati L, Fiorentini $S$, Caruso A: HIV-I matrix protein pl7 binds to monocytes and selectively stimulates MCP-I secretion: role of transcriptional factor AP-I. Cell Microbiol 2008, 10:655-666.

31. Boasso A, Hardy AW, Landay AL, Martinson JL, Anderson SA, Dolan MJ, Clerici M, Shearer GM: PDL-I upregulation on monocytes and $T$ cells by HIV via type I interferon: restricted expression of type I interferon receptor by CCR5-expressing leukocytes. Clin Immunol 2008, I 29:I32-I44.

32. Meier A, Bagchi A, Sidhu HK, Alter G, Suscovich TJ, Kavanagh DG, Streeck H, Brockman MA, LeGall S, Hellman J, Altfeld M: Upregulation of PD-LI on monocytes and dendritic cells by HIV-I derived TLR ligands. Aids 2008, 22:655-658

33. Sharpe AH, Wherry El, Ahmed R, Freeman G]: The function of programmed cell death $I$ and its ligands in regulating autoimmunity and infection. Nat Immunol 2007, 8:239-245.

34. Kinter AL, Godbout EJ, McNally JP, Sereti I, Roby GA, O'Shea MA, Fauci AS: The common gamma-chain cytokines IL-2, IL-7, ILI5, and IL-2I induce the expression of programmed death-I and its ligands. J Immunol 2008, 181:6738-6746.

35. Merad M, Manz MG: Dendritic cell homeostasis. Blood 2009, I I 3:34|8-3427.
36. Popov S, Chenine AL, Gruber A, Li PL, Ruprecht RM: Long-term productive human immunodeficiency virus infection of CDI a-sorted myeloid dendritic cells. J Virol 2005, 79:602-608.

37. Janas AM, Dong C, Wang JH, Wu L: Productive infection of human immunodeficiency virus type $I$ in dendritic cells requires fusion-mediated viral entry. Virology 2008, 375:442-45I.

38. Garcia E, Nikolic DS, Piguet V: HIV-I replication in dendritic cells occurs through a tetraspanin-containing compartment enriched in AP-3. Traffic 2008, 9:200-2I4.

39. Merad M, Ginhoux F, Collin M: Origin, homeostasis and function of Langerhans cells and other langerin-expressing dendritic cells. Nat Rev Immunol 2008, 8:935-947.

40. de Witte L, Nabatov A, Pion M, Fluitsma D, de Jong MA, de Gruijl T, Piguet $\mathrm{V}$, van Kooyk $Y$, Geijtenbeek TB: Langerin is a natural barrier to HIV-I transmission by Langerhans cells. Nat Med 2007, I3:367-37|.

4I. de Jong MA, de Witte L, Oudhoff MJ, Gringhuis SI, Gallay P, Geijtenbeek TB: TNF-alpha and TLR agonists increase susceptibility to HIV-I transmission by human Langerhans cells ex vivo. J Clin Invest 2008, I I 8:3440-3452.

42. Kawamura T, Koyanagi $Y$, Nakamura $Y$, Ogawa $Y$, Yamashita $A$, Iwamoto T, Ito M, Blauvelt A, Shimada S: Significant virus replication in Langerhans cells following application of HIV to abraded skin: relevance to occupational transmission of HIV. J Immunol 2008, 180:3297-3304.

43. Nair MP, Saiyed ZM, Nair N, Gandhi NH, Rodriguez JW, Boukli N, Provencio-Vasquez E, Malow RM, Miguez-Burbano MJ: Methamphetamine enhances HIV-I infectivity in monocyte derived dendritic cells. J Neuroimmune Pharmacol 2009, 4:129-139.

44. Talloczy Z, Martinez J, Joset D, Ray Y, Gacser A, Toussi S, Mizushima N, Nosanchuk JD, Goldstein H, Loike J, et al.: Methamphetamine inhibits antigen processing, presentation, and phagocytosis. PLoS Pathog 2008, 4:e28.

45. Duvall MG, Lore K, Blaak H, Ambrozak DA, Adams WC, Santos K, Geldmacher C, Mascola JR, McMichael AJ, Jaye A, et al.: Dendritic cells are less susceptible to human immunodeficiency virus type 2 (HIV-2) infection than to HIV-I infection. J Virol 2007, $81:$ : $3486-13498$.

46. Fiorentini S, Riboldi E, Facchetti F, Avolio M, Fabbri M, Tosti G Becker PD, Guzman CA, Sozzani S, Caruso A: HIV-I matrix protein pl7 induces human plasmacytoid dendritic cells to acquire a migratory immature cell phenotype. Proc Natl Acad Sci USA 2008, 105:3867-3872.

47. Chaudhry A, Das SR, Hussain A, Mayor S, George A, Bal V, Jameel S, Rath S: The Nef protein of HIV-I induces loss of cell surface costimulatory molecules CD80 and CD86 in APCs. J Immunol 2005, 175:4566-4574.

48. Quaranta MG, Tritarelli E, Giordani L, Viora M: HIV-I Nef induces dendritic cell differentiation: a possible mechanism of uninfected CD4(+) T cell activation. Exp Cell Res 2002, 275:243-254.

49. Meyers JH, Justement JS, Hallahan CW, Blair ET, Sun YA, O'Shea MA, Roby G, Kottilil S, Moir S, Kovacs CM, et al: Impact of HIV on cell survival and antiviral activity of plasmacytoid dendritic cells. PLoS ONE 2007, 2:e458.

50. Groot F, van Capel TM, Kapsenberg ML, Berkhout B, de Jong EC Opposing roles of blood myeloid and plasmacytoid dendritic cells in HIV-I infection of T cells: transmission facilitation versus replication inhibition. Blood 2006, 108: 1957-1964.

51. Muller-Trutwin M, Hosmalin A: Role for plasmacytoid dendritic cells in anti-HIV innate immunity. Immunol Cell Biol 2005, 83:578-583.

52. Boasso A, Herbeuval JP, Hardy AW, Anderson SA, Dolan MJ, Fuchs $D$, Shearer GM: HIV inhibits CD4+ T-cell proliferation by inducing indoleamine 2,3-dioxygenase in plasmacytoid dendritic cells. Blood 2007, 109:335 I-3359.

53. Manches O, Munn D, Fallahi A, Lifson J, Chaperot L, Plumas J, Bhardwaj N: HIV-activated human plasmacytoid DCs induce Tregs through an indoleamine 2,3-dioxygenase-dependent mechanism. I Clin Invest 2008, I I 8:343 I-3439.

54. Chougnet C, Gessani S: Role of gp I 20 in dendritic cell dysfunction in HIV infection. J Leukoc Biol 2006, 80:994-1000.

55. Martinson JA, Roman-Gonzalez A, Tenorio AR, Montoya CJ, Gichinga CN, Rugeles MT, Tomai M, Krieg AM, Ghanekar S, Baum LL, Landay $A L$ : Dendritic cells from HIV-I infected individuals are less responsive to toll-like receptor (TLR) ligands. Cell Immunol 2007, 250:75-84 
56. Tilton IC, Manion MM, Luskin MR, Johnson AJ, Patamawenu AA, Hallahan CW, Cogliano-Shutta NA, Mican JM, Davey RT Jr, Kottilil S, et al.: Human immunodeficiency virus viremia induces plasmacytoid dendritic cell activation in vivo and diminished alpha interferon production in vitro. J Virol 2008, 82:3997-4006.

57. Mandl JN, Barry AP, Vanderford TH, Kozyr N, Chavan R, Klucking S, Barrat FJ, Coffman RL, Staprans SI, Feinberg MB: Divergent TLR7 and TLR9 signaling and type I interferon production distinguish pathogenic and nonpathogenic AIDS virus infections. Nat Med 2008, I4: I077-1087.

58. Dong C, Janas AM, Wang JH, Olson WJ, Wu L: Characterization of human immunodeficiency virus type I replication in immature and mature dendritic cells reveals dissociable cisand trans-infection. J Virol 2007, 81: I I352-I I362.

59. Wang JH, Janas AM, Olson WJ, Wu L: Functionally distinct transmission of human immunodeficiency virus type I mediated by immature and mature dendritic cells. J Virol 2007, 8 I:8933-8943.

60. McDonald D, Wu L, Bohks SM, KewalRamani VN, Unutmaz D, Hope T]: Recruitment of HIV and its receptors to dendritic cell-T cell junctions. Science 2003, 300: I295-। 297.

6I. Wu L: Biology of HIV Mucosal Transmission. Curr Opin HIV AIDS 2008, 3:534-540.

62. Wang JH, Janas AM, Olson WJ, KewalRamani VN, Wu L: CD4 coex pression regulates DC-SIGN-mediated transmission of human immunodeficiency virus type I. J Virol 2007, 8I:2497-2507.

63. Wang JH, Wells C, Wu L: Macropinocytosis and cytoskeleton contribute to dendritic cell-mediated HIV-I transmission to CD4+ T cells. Virology 2008, 38 I: |43-I54.

64. Yu HJ, Reuter MA, McDonald D: HIV traffics through a specialized, surface-accessible intracellular compartment during trans-infection of $\mathbf{T}$ cells by mature dendritic cells. PLoS Pathog 2008, 4:e 1000I34.

65. Cavrois M, Neidleman J, Kreisberg JF, Greene WC: In vitro derived dendritic cells trans-infect CD4 $\mathrm{T}$ cells primarily with surface-bound HIV-I virions. PLoS Pathog 2007, 3:e4.

66. Hatch SC, Archer J, Gummuluru S: Glycosphingolipid Composition of Human Immundeficiency Virus Type-I Particles is a Crucial Determinant for Dendritic Cell-Mediated HIV-I Trans Infection. J Virol 2009, 83:3496-3506.

67. Wang $\mathrm{H}$, Kwas $\mathrm{C}$, Wu L: Intercellular adhesion molecule

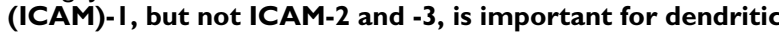
cell-mediated human immunodeficiency virus type-I transmission. J Virol 2009, 83:4195-4204.

68. Groot F, Kuijpers TW, Berkhout B, de Jong EC: Dendritic cellmediated HIV-I transmission to T cells of LAD-I patients is impaired due to the defect in LFA-I. Retrovirology 2006, 3:75.

69. Puigdomenech I, Massanella M, Izquierdo-Useros N, Ruiz-Hernandez R, Curriu M, Bofill M, Martinez-Picado J, Juan M, Clotet B, Blanco HIV transfer between CD4 T cells does not require LFA-I binding to ICAM-I and is governed by the interaction of HIV envelope glycoprotein with CD4. Retrovirology 2008, 5:32

70. Gaiha GD, Dong T, Palaniyar N, Mitchell DA, Reid KB, Clark HW Surfactant protein $A$ binds to HIV and inhibits direct infection of CD4+ cells, but enhances dendritic cell-mediated viral transfer. J Immunol 2008, I 8I:601-609.

7I. Wiley RD, Gummuluru S: Immature dendritic cell-derived exosomes can mediate HIV-I trans infection. Proc Natl Acad Sci USA 2006, I 03:738-743.

72. Izquierdo-Useros N, Naranjo-Gomez M, Archer J, Hatch SC, Erkizia I, Blanco J, Borras FE, Puertas MC, Connor JH, Fernandez-Figueras MT, et al.: Capture and transfer of HIV-I particles by mature dendritic cells converges with the exosome-dissemination pathway. Blood 2009, I I 3:2732-4 I.

73. Sowinski S, Jolly C, Berninghausen O, Purbhoo MA, Chauveau A Kohler K, Oddos S, Eissmann P, Brodsky FM, Hopkins C, et al: Membrane nanotubes physically connect $T$ cells over long distances presenting a novel route for HIV-I transmission. Nat Cell Biol 2008, 10:211-219.

74. Sherer NM, Lehmann MJ, Jimenez-Soto LF, Horensavitz C, Pypaert M, Mothes W: Retroviruses can establish filopodial bridges for efficient cell-to-cell transmission. Nat Cell Biol 2007, 9:310-315.

75. St John EP, Zariffard MR, Martinson JA, Simoes JA, Landay AL, Spear GT: Effect of mucosal fluid from women with bacterial vaginosis on HIV trans-infection mediated by dendritic cells. Virology 2009, 385:22-27.
76. Nabatov AA, de Jong MA, de Witte L, Bulgheresi S, Geijtenbeek TB: C-type lectin Mermaid inhibits dendritic cell mediated HIVI transmission to CD4+ T cells. Virology 2008, 378:323-328.

77. Requena M, Bouhlal H, Nasreddine N, Saidi H, Gody IC, Aubry S, Gresenguet G, Kazatchkine MD, Sekaly RP, Belec L, Hocini H: Inhibition of HIV-I transmission in trans from dendritic cells to CD4+ $T$ lymphocytes by natural antibodies to the CRD domain of DC-SIGN purified from breast milk and intravenous immunoglobulins. Immunology 2008, I 23:508-5 I8.

78. Barat C, Gilbert C, Imbeault M, Tremblay MJ: Extracellular ATP reduces HIV-I transfer from immature dendritic cells to CD4+ T lymphocytes. Retrovirology 2008, 5:30.

79. Mueller NH, Gilden DH, Cohrs RJ, Mahalingam R, Nagel MA: Varicella zoster virus infection: clinical features, molecular pathogenesis of disease, and latency. Neurol Clin 2008 26:675-697.

80. Reeves $M$, Sinclair J: Aspects of human cytomegalovirus latency and reactivation. Curr Top Microbiol Immunol 2008, 325:297-3 I 3

81. Divito S, Cherpes TL, Hendricks RL: A triple entente: virus, neurons, and CD8+ T cells maintain HSV-I latency. Immunol Res 2006, 36:119-126.

82. Bouzar $A B$, Willems L: How HTLV-I may subvert miRNAs for persistence and transformation. Retrovirology 2008, 5: I0I.

83. Palmer S, Maldarelli F, Wiegand A, Bernstein B, Hanna GJ, Brun SC, Kempf DJ, Mellors JW, Coffin JM, King MS: Low-level viremia persists for at least 7 years in patients on suppressive antiretroviral therapy. Proc Natl Acad Sci USA 2008, I05:3879-3884.

84. Varbanov M, Espert L, Biard-Piechaczyk M: Mechanisms of CD4 Tcell depletion triggered by HIV-I viral proteins. AIDS Rev 2006, 8:22I-236.

85. Nottet HS, van Dijk SJ, Fanoy EB, Goedegebuure IW, de Jong D, Vrisekoop N, Baarle DV, Boltz V, Palmer S, Borleffs JC, Boucher CA: HIV-I Can Persist in Aged Memory CD4+ T Lymphocytes With Minimal Signs of Evolution After 8.3 Years of Effective Highly Active Antiretroviral Therapy. J Acquir Immune Defic Syndr 2009, 50:345-353.

86. Siliciano JD, Kajdas J, Finzi D, Quinn TC, Chadwick K, Margolick JB Kovacs C, Gange SJ, Siliciano RF: Long-term follow-up studies confirm the stability of the latent reservoir for HIV-I in resting CD4+ T cells. Nat Med 2003, 9:727-728.

87. McElrath MJ, Steinman RM, Cohn ZA: Latent HIV-I infection in enriched populations of blood monocytes and $T$ cells from seropositive patients. J Clin Invest I99I, 87:27-30.

88. Mikovits JA, Lohrey NC, Schulof R, Courtless J, Ruscetti FW: Activation of infectious virus from latent human immunodeficiency virus infection of monocytes in vivo. J Clin Invest 1992 , 90:|486-|49|.

89. Sonza S, Mutimer HP, Oelrichs R, Jardine D, Harvey K, Dunne A, Pur cell DF, Birch C, Crowe SM: Monocytes harbour replicationcompetent, non-latent HIV-I in patients on highly active antiretroviral therapy. Aids 200I, I 5:17-22.

90. Lambotte O, Taoufik Y, de Goer MG, Wallon C, Goujard C, Delfraissy JF: Detection of infectious HIV in circulating monocytes from patients on prolonged highly active antiretroviral therapy. J Acquir Immune Defic Syndr 2000, 23: I I4- I I9.

91. Zhu T, Muthui D, Holte S, Nickle D, Feng F, Brodie S, Hwangbo $Y$, Mullins Jl, Corey L: Evidence for human immunodeficiency virus type I replication in vivo in CD I4(+) monocytes and its potential role as a source of virus in patients on highly active antiretroviral therapy. J Virol 2002, 76:707-7I6.

92. Ellery PJ, Tippett E, Chiu YL, Paukovics G, Cameron PU, Solomon A Lewin SR, Gorry PR, Jaworowski A, Greene WC, et al.: The CD I 6+ monocyte subset is more permissive to infection and preferentially harbors HIV-I in vivo. I Immunol 2007, I 78:658I-6589.

93. Jaworowski A, Kamwendo DD, Ellery P, Sonza S, Mwapasa V, Tadesse E, Molyneux ME, Rogerson SJ, Meshnick SR, Crowe SM: CDI6+ monocyte subset preferentially harbors HIV-I and is expanded in pregnant Malawian women with Plasmodium falciparum malaria and HIV-I infection. J Infect Dis 2007, 196:38-42.

94. Dong C, Kwas C, Wu L: Transcriptional restriction of human immunodeficiency virus type-I gene expression in undifferentiated primary monocytes. I Virol 2009, 83:35 I 8-3527.

95. Bres $\mathrm{V}$, Yoh SM, Jones KA: The multi-tasking P-TEFb complex. Curr Opin Cell Biol 2008, 20:334-340.

96. Rice AP, Herrmann CH: Regulation of TAK/P-TEFb in CD4+ T lymphocytes and macrophages. Curr HIV Res 2003, I:395-404. 
97. Liou LY, Herrmann CH, Rice AP: Transient induction of cyclin TI during human macrophage differentiation regulates human immunodeficiency virus type I Tat transactivation function. J Virol 2002, 76: I0579-10587.

98. Garber ME, Mayall TP, Suess EM, Meisenhelder J, Thompson NE, Jones KA: CDK9 autophosphorylation regulates high-affinity binding of the human immunodeficiency virus type I tat-P. TEFb complex to TAR RNA. Mol Cell Biol 2000, 20:6958-6969.

99. Nobile C, Petit C, Moris A, Skrabal K, Abastado JP, Mammano F, Schwartz O: Covert human immunodeficiency virus replication in dendritic cells and in DC-SIGN-expressing cells promotes long-term transmission to lymphocytes. J Virol 2005, 79:5386-5399.

100. Burleigh L, Lozach PY, Schiffer C, Staropoli I, Pezo V, Porrot F, Canque B, Virelizier JL, Arenzana-Seisdedos F, Amara A: Infection of dendritic cells (DCs), not DC-SIGN-mediated internalization of human immunodeficiency virus, is required for longterm transfer of virus to T cells. I Virol 2006, 80:2949-2957.

10I. Lore K, Smed-Sorensen A, Vasudevan J, Mascola JR, Koup RA: Myeloid and plasmacytoid dendritic cells transfer HIV-I preferentially to antigen-specific CD4+ $\mathbf{T}$ cells. J Exp Med 2005, 20I:2023-2033.

102. Pelchen-Matthews A, Kramer B, Marsh M: Infectious HIV-I assembles in late endosomes in primary macrophages. J Cell Biol 2003, 162:443-455.

103. Deneka M, Pelchen-Matthews A, Byland R, Ruiz-Mateos E, Marsh M: In macrophages, HIV-I assembles into an intracellular plasma membrane domain containing the tetraspanins CD8 I, CD9, and CD53. J Cell Biol 2007, I77:329-34I.

104. Welsch S, Keppler OT, Habermann A, Allespach I, Krijnse-Locker J, Krausslich HG: HIV-I buds predominantly at the plasma membrane of primary human macrophages. PLoS Pathog 2007, 3:e36.

105. Carter CA, Ehrlich LS: Cell biology of HIV-I infection of macrophages. Annu Rev Microbiol 2008, 62:425-443.

106. Burton GF, Keele BF, Estes JD, Thacker TC, Gartner S: Follicular dendritic cell contributions to HIV pathogenesis. Semin Immunol 2002, 14:275-284.

107. Haase AT, Henry K, Zupancic M, Sedgewick G, Faust RA, Melroe H, Cavert W, Gebhard K, Staskus K, Zhang ZQ, et al.: Quantitative image analysis of HIV-I infection in lymphoid tissue. Science 1996, 274:985-989.

108. Heath SL, Tew JG, Tew JG, Szakal AK, Burton GF: Follicular dendritic cells and human immunodeficiency virus infectivity. Nature 1995, 377:740-744.

109. Spiegel H, Herbst H, Niedobitek G, Foss HD, Stein H: Follicular dendritic cells are a major reservoir for human immunodeficiency virus type $I$ in lymphoid tissues facilitating infection of CD4+ T-helper cells. Am J Pathol I992, 140:15-22.

110. Smith BA, Gartner S, Liu Y, Perelson AS, Stilianakis NI, Keele BF Kerkering TM, Ferreira-Gonzalez A, Szakal AK, Tew JG, Burton GF: Persistence of infectious HIV on follicular dendritic cells. J Immunol 200I, 166:690-696.

III. Keele BF, Tazi L, Gartner S, Liu Y, Burgon TB, Estes JD, Thacker TC, Crandall KA, McArthur JC, Burton GF: Characterization of the follicular dendritic cell reservoir of human immunodeficiency virus type I. J Virol 2008, 82:5548-556I.

I 12. Otero M, Nunnari G, Leto D, Sullivan J, Wang FX, Frank I, Xu Y, Patel C, Dornadula G, Kulkosky J, Pomerantz RJ: Peripheral blood Dendritic cells are not a major reservoir for HIV type $I$ in infected individuals on virally suppressive HAART. AIDS Res Hum Retroviruses 2003, 19:1097-I I03.

113. Boy SC, van Heerden MB, Wolfaardt M, Cockeran R, Gema E, van Heerden WF: An investigation of the role of oral epithelial cells and Langerhans cells as possible HIV viral reservoirs. J Oral Pathol Med 2009, 38: I I 4-II 9 .

114. Isgro A, Leti W, De Santis W, Marziali M, Esposito A, Fimiani C, Luzi G, Pinti M, Cossarizza A, Aiuti F, Mezzaroma I: Altered clonogenic capability and stromal cell function characterize bone marrow of HIV-infected subjects with low CD4+ T cell counts despite viral suppression during HAART. Clin Infect Dis 2008, 46: $1902-1910$

I 15. Baenziger S, Ziegler P, Mazzucchelli L, Bronz L, Speck RF, Manz MG: Human $T$ cell development and HIV infection in human hemato-lymphoid system mice. Curr Top Microbiol Immunol 2008, 324: $|25-| 3 \mid$.
116. Dorival C, Brizzi F, Lelievre JD, Sol-Foulon N, Six E, Henry A, AndreSchmutz I, Cavazzana-Calvo M, Coulombel L, Estaquier J, et al:: HIVI Nef protein expression in human CD34+ progenitors impairs the differentiation of an early T/NK cell precursor. Virology 2008, 377:207-215.

117. Alexaki A, Liu Y, Wigdahl B: Cellular reservoirs of HIV-I and their role in viral persistence. Curr HIV Res 2008, 6:388-400.

1 18. Alexaki A, Wigdahl B: HIV-I infection of bone marrow hematopoietic progenitor cells and their role in trafficking and viral dissemination. PLoS Pathog 2008, 4: el0002I5.

119. Trobridge GD, Beard BC, Gooch C, Wohlfahrt M, Olsen P, Fletcher J. Malik P, Kiem HP: Efficient transduction of pigtailed macaque hematopoietic repopulating cells with HIV-based lentiviral vectors. Blood 2008, II I:5537-5543.

120. Mitsuyasu RT, Merigan TC, Carr A, Zack JA, Winters MA, Workman C, Bloch M, Lalezari J, Becker S, Thornton L, et al:: Phase 2 gene therapy trial of an anti-HIV ribozyme in autologous CD34+ cells. Nat Med 2009, I 5:285-292.

121. Pearson R, Kim YK, Hokello J, Lassen K, Friedman J, Tyagi M, Karn J: Epigenetic silencing of human immunodeficiency virus (HIV) transcription by formation of restrictive chromatin structures at the viral long terminal repeat drives the progressive entry of HIV into latency. J Virol 2008, 82: | 229|- 12303.

122. Vanti M, Gallastegui E, Respaldiza I, Rodriguez-Gil A, Gomez-Herreros $F$, Jimeno-Gonzalez S, Jordan A, Chavez S: Yeast genetic analysis reveals the involvement of chromatin reassembly factors in repressing HIV-I basal transcription. PLOS Genet 2009, 5: el 000339.

123. Burnett JC, Miller-Jensen K, Shah PS, Arkin AP, Schaffer DV: Control of stochastic gene expression by host factors at the HIV promoter. PLoS Pathog 2009, 5: 1000260.

124. Jochmann R, Thurau M, Jung S, Hofmann C, Naschberger E, Kremmer E, Harrer T, Miller M, Schaft N, Sturzl M: O-linked N-Acetylglucosaminylation of SpI Inhibits the Human Immunodeficiency Virus Type-I Promoter. J Virol 2009, 83:3704-37I8.

125. Bosque A, Planelles V: Induction of HIV-I latency and reactivation in primary memory CD4+ T cells. Blood 2009, I I 3:58-65.

126. Huang J, Wang F, Argyris E, Chen K, Liang Z, Tian H, Huang W, Squires K, Verlinghieri G, Zhang H: Cellular microRNAs contribute to HIV-I latency in resting primary CD4+ $T$ lymphocytes. Nat Med 2007, 13:124I-I247.

127. Zhang H: Reversal of HIV-I latency with anti-microRNA inhibitors. Int J Biochem Cell Biol 2009, 41:45 I-454.

128. Lassen KG, Ramyar KX, Bailey JR, Zhou Y, Siliciano RF: Nuclear retention of multiply spliced HIV-I RNA in resting CD4+ T cells. PLoS Pathog 2006, 2:e68.

129. Jeeninga RE, Westerhout EM, van Gerven ML, Berkhout B: HIV-I latency in actively dividing human $\mathbf{T}$ cell lines. Retrovirology 2008, 5:37.

130. Nazari R, Joshi S: CCR5 as target for HIV-I gene therapy. Curr Gene Ther 2008, 8:264-272.

13I. Lieberman-Blum SS, Fung HB, Bandres JC: Maraviroc: a CCR5receptor antagonist for the treatment of HIV-I infection. Clin Ther 2008, 30:1228- I250.

132. Rinaldo CR: Dendritic cell-based human immunodeficiency virus vaccine. J Intern Med 2009, 265: I38-I 58 .

133. Stybayeva G, Zhu H, Ramanculov E, Dandekar S, George M, Revzin A: Micropatterned co-cultures of T-lymphocytes and epithelial cells as a model of mucosal immune system. Biochem Biophys Res Commun 2009, 380:575-580.

134. Van Herrewege Y, Michiels J, Waeytens A, De Boeck G, Salden E, Heyndrickx L, Mooter G van den, de Bethune MP, Andries K, Lewi P, et al.: A dual chamber model of female cervical mucosa for the study of HIV transmission and for the evaluation of candidate HIV microbicides. Antiviral Res 2007, 74: I I I- I24.

135. Han Y, Wind-Rotolo M, Yang HC, Siliciano JD, Siliciano RF: Experimental approaches to the study of HIV-I latency. Nat Rev Microbiol 2007, 5:95-106.

136. Denton PW, Garcia JV: Novel humanized murine models for HIV research. Curr HIVIAIDS Rep 2009, 6:13-19.

137. Kumar P, Ban HS, Kim SS, Wu H, Pearson T, Greiner DL, Laouar A, Yao J, Haridas V, Habiro K, et al.: T cell-specific siRNA delivery suppresses HIV-I infection in humanized mice. Cell 2008, 134:577-586. 